\title{
Merkel Cell Carcinoma Pathologic Primary Tumor TNM Finding v7
}

National Cancer Institute

\section{Source}

National Cancer Institute. Merkel Cell Carcinoma Pathologic Primary Tumor TNM Finding v7. NCl Thesaurus. Code C88499.

A pathologic finding about one or more characteristics of Merkel cell carcinoma, following the rules of the TNM AJCC V7 classification system as they pertain to staging of the primary tumor. The TNM pathologic and clinical primary tumor classifications of Merkel cell carcinoma are the same. (from AJCC 7th Ed.) 